\title{
THE ROLE OF MARITIME ENGLISH IN THE CURRENT GEO-POLITICAL CONTEXT
}

\author{
Irina-Stefania GHEORGHE (ALBU), M.A. ${ }^{1}$

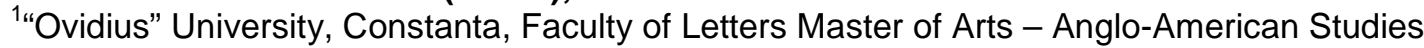 \\ albu.irina@rocketmail.com
}

\begin{abstract}
For the present article, I propose to analyse some of the implications of the 2010 Manila Amendments to the STCW Convention and Code, as well as their application and enforcement, and comment upon the changes made, while focusing on how these changes affect the average Romanian seafarer. Furthermore, due to the ever-changing Geo-Political context, especially considering Brexit and the United States' policies regarding immigration, as well as China's growing influence on the Asian markets, in the wake of President Trump's refusal to sign the Trans-Pacific Partnership, many industries have had to rethink their businesses and shipping may soon follow. Even though the role of the English language in the shipping industry does not seem to change for the moment, it is worth to take a moment to analyse the impact of these changes, in a world where English is not the official language of any of the countries of the European Union.
\end{abstract}

Key words: Maritime English, Brexit, Trans-Pacific Partnership, communication.

In a world where globalization seems to have ran its course, a world saturated of "togetherness", a world where nations seem to fight back, in order to preserve their individuality and culture, what is the place of the English language?

Due to the rapid developments of technology, which has made travelling so much easier in the past decades, as well as the international trend inclining towards "a global village", encompassing not only free trade agreements and the elimination of visas for certain states, but also taking into account the harsh living conditions in some parts of the world, and the promise of a better future in others, the modern world seems to be in constant motion. We are currently witnessing the effects of this process, which seems to have reached a point of no return, a point in which some countries are unable to keep their own people safe, not to mention to assure the safety of the people who have fled their home countries in hope of a brighter future.

Some part of the advancements which have made available travelling long distances have also aided in the development of the shipping industry as well. According to Barry Glassman, a contributor to the Forbes magazine,

From refrigerated freighters and container ships to car carriers and supertankers, the world's shipping industry has played an incredibly key role in transporting $90 \%$ of the world's food, products and energy while helping to transform the global economy along the way. Each year, some 86,000 ships move more than 9 billion tons of cargo - more than a ton for each person on the planet - across our seas each year. [1]
This goes to prove that the shipping industry has managed not only to become one of the most important industries in many countries, but it has also helped connect the world. Some countries with a desert climate, where agriculture is prohibitive, rely heavily on the import of goods and services and the export of oil. This has lead to an externalization of services, not only the ones indirectly connected to trading, but in the shipping industry itself. Judging strictly from the point of view of shipowners, maximizing profits would be easily attainable by hiring cheap workforce.

This has allowed for cities with access to the high seas to further expand into academic centres, providing the world with competent maritime officers. So how does a Romanian seafarer get to be part of a team which transports electronics from China to Brazil? What does it take for a seafarer to become a part of an international crew? In addition to the main answer, which is related to either the bridge or engine department, each with their own specific tasks, the other most notable answer is quite obvious - the English Language. It would be quite impossible to manage a job as a seafarer in an international context, without being in the least bit acquainted with the English Language in general.

Nevertheless, managing a simple conversation in English would not suffice in a multicultural environment in which one's safety as well as the safety of one's colleagues resides in understanding and being understood. The specific nature of the vocabulary leaves little room for bargaining; and even with the recent tendency to overlook the definitions and classifications and focus on the teaching and methods, Maritime English still needs some context. It seems the more Maritime English is being analyzed, the more controversies arise; as Drown claims, "over the past 25 years, Maritime English has accumulated fourteen different definitions, with no 


\section{"Mircea cel Batran" Naval Academy Scientific Bulletin, Volume XX - 2017 - Issue 1 The journal is indexed in: PROQUEST / DOAJ / Crossref / EBSCOhost / INDEX COPERNICUS / DRJI / OAJI I JOURNAL INDEX I I2OR / SCIENCE LIBRARY INDEX / Google Scholar / Academic Keys/ ROAD Open Access I Academic Resources / Scientific Indexing Services / SCIPIO / JIFACTOR}

consensus on content and scope." [2] Regardless of the controversies surrounding the subject matter and field of application, the impact of Maritime English is irrefutable. In a world where your next employment opportunity is an e-mail or a phone call away, a good command of the English language should be a prerequisite:

[...] as the percentage of
seafarers in the shipping industry
shrinks and the number of
internationally employed shorebased
personnel increases, Maritime English
has become an essential career tool,
permitting mobility, flexibility and
competitiveness. [3]

This translates into fewer people onboard the ships, people who are better qualified and up to date with the use of the new technology. Even taking into account the use of the new machinery onboard, one thing has always been constant the need for understanding. The fact that technology has evolved in such a way that the only incidents that occur do so because of basic human error, means that the industry goal of "Zero incidents" is closer than we imagined, and resides only in one's ability to understand and make himself / herself understood.

According to professor Ziarati, "(IMO) (2005) has reported that by far majority of accidents at sea are caused by human error, [...] due to poor standards of Maritime English" [4] This goes on to prove that communication is as important as the technical management of a vessel. As such, it is important for the shipping industry in general to keep people motivated, and to continue to develop the mariners' English Language skills. However, due to the poor management of the teaching of Maritime English, there is no clear standard yet. Of course, attempts have been made to right this, and I would just like to mention the MarTEL project, as well as Clive Cole and Peter Treckner's "The Yardstick for Maritime English STCW Assessment Purposes". Although many more experiments have been made, a unification of this process is rather difficult, considering the lack of a consensus regarding the form of teaching: should Maritime English be taught as a lingua franca, as a simple terminology or as a whole language?

Many issues surrounding the standardization of Maritime English are also accounted for in the national legislation of each country, as Maritime English is taught in Universities, and is tested for in Maritime Centres, which are also legislated by the Governments. This fact is also highlighted by Annamaria Gabrielli, who mentions that

\begin{abstract}
Another difficulty in meeting
ME standards from a global perspective is that national legislation, on which local training is based, defines learning outcomes for cadets, whereas cadet competence levels are prompted by the international requirements of the IMO's 171 member countries. Local legislation and requirements do not always mirror or accurately translate international counterparts. An ongoing, functional, and relevant international dialogue between IMO member countries is therefore imperative to make these two dimensions converge. [5]
\end{abstract}

This is also the case in Romania, according to the Romanian Maritime Training Centre, English Language is no longer a compulsory IMO course for officers onboard ships, the course being available only for ratings. Of course, most companies have in place English Language tests when hiring a crewmember for the first time, for any rank, however, a unification of the testing at an international level might help personnel move more freely, and it would also raise the bar for the existing sailors.

The role and perception of the English Language seems to change around the world, as the geopolitical context moves from globalization towards a more traditional line of preserving cultures. Although the dichotomy of national versus international is not fully applied, the shift in paradigm from global to nationwide seems to bring with itself some sort of stubborn turn towards individuality. This is echoed most recently in the claim that the English Language would no longer remain an official language of the European Union, as it is not the first choice of any of the remaining member states:

English, the world's second language and the main working tongue of EU institutions, may no longer be an official language of the European Union once Britain leaves the bloc, a senior EU lawmaker said on Monday.

The symbolic, if impractical, move would further reduce London's influence on the continent, and infuriate the Irish.

Each member state has the right to nominate one EU idiom. Although English is the most spoken language in Europe, and an official language in three member states, only Britain legally chose it in Brussels. 


\section{"Mircea cel Batran" Naval Academy Scientific Bulletin, Volume XX - 2017 - Issue 1 The journal is indexed in: PROQUEST / DOAJ / Crossref / EBSCOhost / INDEX COPERNICUS / DRJI / OAJI I JOURNAL INDEX I I2OR / SCIENCE LIBRARY INDEX / Google Scholar / Academic Keys/ ROAD Open Access I Academic Resources / Scientific Indexing Services / SCIPIO / JIFACTOR}

Ireland chose Gaelic. Malta picked Maltese.[6]

Of course, the declarations seem rather childish, as a response to the United Kingdom's decision to leave the European Union, in a time like this. Furthermore, one of the reasons why Ireland chose Gaelic and Malta picked Maltese was that the United Kingdom had already chosen English as its EU idiom, and the idea of diversity was still coveted. It would be no surprise, then, that either Ireland or Malta would change their EU idiom again, as the move to entirely remove the English Language from the European Union would translate to a terrible change.

Due to the nature of the expanding world we live in, language has always been the first barrier to overcome. Nevertheless, because of the worldwide integration sought out in the last decades, trade has been one of the most important processes in language exchange. One of the most important trade agreements in the last decades, the Trans-Pacific Partnership, has been dismissed by the United States' President, Donald Trump, whose focus seems to be on the internal affairs of the US. President Trump's decision seems to benefit China, which "hadn't been included in the partnership" [7] Still, China is focused on issues in the immediate vicinity, with the addition of new buildings on the artificial islands in the South China Sea, a fact which has attracted negative comments, not just from the neighboring countries, which also claim the territory, but also from the United States, which realize the danger of a conflict in the area. The latest comments on behalf of a senior Chinese politician, who defends China's right to build facilities in the South China Sea, suggesting it is only for the sake of the safety of navigation and rescue efforts, have "[...] Washington accusing Beijing of militarising and obstructing freedom of navigation in the waters through its construction activities." [8]

This dormant conflict, along with President Trump's general attitude towards international policies, as well as China's economic growth and increased influence in the area, and status as the world's largest trader may as well shift the focus in shipping too. In his book, The Trans Pacific Partnership, China and India: Economic and Political Implications, Amitendu Palit, referencing Pascal Lamy's speech as director of the World Trade Organization, referring to China, India and Brazil, and suggesting they are "no longer policy takers, and were influencing the course and evolution of international trade in several significant ways." [9] We have no way of knowing what would happen, should these countries choose to refresh the paradigm of shipping.
For the moment, the English language seems to keep its place in the world. Even more so Maritime English, with the recent trends in teaching and the latest tools available; with the development in communication technologies of the last decades, the world has soon followed. One of the last bastions to keep us together is the English language. For how long, it remains to be seen. 
"Mircea cel Batran" Naval Academy Scientific Bulletin, Volume XX - 2017 - Issue 1 The journal is indexed in: PROQUEST / DOAJ / Crossref / EBSCOhost / INDEX COPERNICUS / DRJI / OAJI I JOURNAL INDEX I I2OR / SCIENCE LIBRARY INDEX / Google Scholar / Academic Keys/ ROAD Open Access I Academic Resources / Scientific Indexing Services / SCIPIO / JIFACTOR

\section{Bibliography}

[1] Glassman B. Forbes Welcome [Internet]. Forbes.com. 2017 [cited 6 January 2017]. Available from: http://www.forbes.com/sites/advisor/2013/01/02/shipping-globalizations-lifeblood/

[2] Drown D, Anstey F, Mercer R, Jeffrey G, Cross S. Different measures: standards of education and examinations towards STCW competency. IMLA-23. Durban: Durban University of Technology; 2015. p. 211-223.

[3] Cole CTrenkner P. Whither Maritime English?. IMLA-24. Myanmar; 2012. p. 3-19.

[4] Ziarati R. Safety At Sea - Applying Pareto Analysis. World Maritime Technology Conference. London: World Maritime Technology Conference; 2006.

[5] Gabrielli A. Standardising Maritime English Training and Assessment Through International Coordination of Content-Based Instruction. Scripta Manent. 2016;10(2):52-62.

[6] Guarascio F. Au revoir anglais? EU could drop English as official tongue after Brexit. Reuters [Internet]. 2016 [cited 20 January 2017];. Available from: http://www.reuters.com/article/us-britain-eu-languageidUSKCNOZD2AC

[7] Rauhala EFifield A. Trump TPP move seen as win for China, but Beijing isn't celebrating. The Washington Post [Internet]. 2017 [cited 3 February 2017]; . Available from: https://www.washingtonpost.com/world/trumptpp-move-seen-as-win-for-china-but-beiijing-isnt-celebrating/2017/01/24/f0e5ffcc-e188-11e6-a419eefe8eff0835 story.html

[8] Mai J. China takes another jab at US in war of words over South China Sea. CNBC [Internet]. 2017 [cited 4 March 2017];. Available from: http://www.cnbc.com/2017/03/02/china-takes-another-jab-at-us-in-war-ofwords-over-south-china-sea.html

[9] Palit A. The Trans-Pacific Partnership, China and India. 1st ed. Abingdon: Routledge; 2014. 